\title{
High diversity of nitrogen-fixing bacteria in the upper reaches of the Heihe River, northwestern China
}

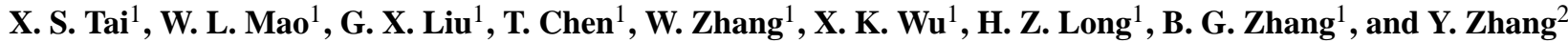 \\ ${ }^{1}$ Cold and Arid Regions Environmental and Engineering Research Institute, Chinese Academy of Sciences, \\ Lanzhou 730000, China \\ ${ }^{2}$ Hexi University, Zhangye 734000, China
}

Correspondence to: G. X. Liu (liugx@1zb.ac.cn)

Received: 5 February 2013 - Published in Biogeosciences Discuss.: 13 March 2013

Revised: 12 July 2013 - Accepted: 12 July 2013 - Published: 21 August 2013

\begin{abstract}
Vegetation plays a key role in water conservation in the southern Qilian Mountains (northwestern China), located in the upper reaches of the Heihe River. Nitrogen-fixing bacteria are crucial for the protection of the nitrogen supply for vegetation in the region. In the present study, nifH gene clone libraries were established to determine differences between the nitrogen-fixing bacterial communities of the Potentilla parvifolia shrubland and the Carex alrofusca meadow in the southern Qilian Mountains. All of the identified nitrogen-fixing bacterial clones belonged to the Proteobacteria. At the genus level, Azospirillum was only detected in the shrubland soil, while Thiocapsa, Derxia, Ectothiorhodospira, Mesorhizobium, Klebsiella, Ensifer, Methylocella and Pseudomonas were only detected in the meadow soil. The phylogenetic tree was divided into five lineages: lineages I, II and III mainly contained nifH sequences obtained from the meadow soils, while lineage IV was mainly composed of nifH sequences obtained from the shrubland soils. The Shannon-Wiener index of the nifH genes ranged from 1.5 to 2.8 and was higher in the meadow soils than in the shrubland soils. Based on these analyses of diversity and phylogeny, the plant species were hypothesised to influence $\mathrm{N}$ cycling by enhancing the fitness of certain nitrogenfixing taxa. The number of nifH gene copies and colonyforming units (CFUs) of the cultured nitrogen-fixing bacteria were lower in the meadow soils than in the shrubland soils, ranging from $0.4 \times 10^{7}$ to $6.9 \times 10^{7}$ copies $\mathrm{g}^{-1}$ soil and $0.97 \times 10^{6}$ to $12.78 \times 10^{6} \mathrm{~g}^{-1}$ soil, respectively. Redundancy analysis (RDA) revealed that the diversity and number of the nifH gene copies were primarily correlated with aboveground biomass in the shrubland soil. In the meadow soil,
\end{abstract}

nifH gene diversity was most affected by altitude, while copy number was most impacted by soil-available K. These results suggest that the nitrogen-fixing bacterial communities beneath Potentilla were different from those beneath Carex.

\section{Introduction}

Biological nitrogen fixation is an important nitrogen input in many terrestrial environments, and is fundamental to the long-term productivity of vegetation, particularly in areas with low nutrient availability, such as alpine ecosystems (Izquierdo and Nüsslein, 2006; Zhang et al., 2006). Nitrogenfixing bacteria are responsible for nearly one-third of the biologically fixed nitrogen in these ecosystems (Izquierdo and Nüsslein, 2006). Lynch and Hobbie (1988) found that variation in the nitrogen-fixing bacterial community structure has a greater impact on nitrogen fixation rates than do soil characteristics. Nitrogenase is the enzyme responsible for nitrogen fixation, and nifH is the gene that encodes for the iron protein subunit of nitrogenase, which is highly conserved among all nitrogen-fixing groups and serves as an ideal molecular marker for these microorganisms (Deslippe and Egger, 2006). The cloning and sequencing of the nifH gene have provided a large and rapidly expanding database of nifH sequences from a number of diverse environments (Zehr et al., 2003), including cold polar soils (Olson et al., 1998; Deslippe and Egger, 2006; Zhang et al., 2006), aquatic habitats (Steward et al., 2004; Moisander et al., 2008; Hamilton et al., 2011) and agricultural soils (Coelho et al., 2009; Zou et al., 2011). However, the diversity of nitrogen-fixing 
bacteria is still poorly described, and many of these microorganisms are yet to be discovered (as reviewed in Gaby and Buckley, 2011).

The nitrogen-fixing bacterial community can be affected by a number of abiotic and biotic factors. Hamelin et al. (2002) indicated that certain plants mediate favourable niches for nitrogen-fixing bacteria. Plant-specific differences in the nitrogen-fixing bacterial community may be related to plant species, biomass, the chemical composition of litter and root exudates (Shaffer et al., 2000; Bürgmann et al., 2005; Hsu and Buckley, 2009; Knelman et al., 2012). Soil physicochemical factors, such as $\mathrm{pH}$ and water content (Zhan and Sun, 2011), microbial biomass carbon and microbial biomass nitrogen (Hayden et al., 2010), total nitrogen and total potassium (Teng et al., 2009; Hayden et al., 2010), total phosphorus and reactive phosphorus (Reed et al., 2010; Zou et al., 2011; Romero et al., 2012), electrical conductivity (Hayden et al., 2010; Hamilton et al., 2011) and nutrient level (Jasrotia and Ogram, 2008; Zhan and Sun, 2012), have also been identified as drivers of nifH gene diversity and abundance in many environments.

The Heihe River basin is the second-largest inland river basin in the arid regions of northwestern China, which consists of three major geomorphic units: the southern Qilian Mountains, the middle Hexi Corridor and the northern Alxa Highland (Wang et al., 2009). The southern Qilian Mountains, located in the upper reaches of the Heihe River basin, is hydrologically and ecologically the most important unit, functioning as the water source for agricultural irrigation in the Hexi Corridor and maintaining the ecological viability of the northern Alxa Highland (Ma and Frank, 2006). However, a recent global-scale analysis of soil nitrogen by Cleveland and Liptzin (2007) indicated that the soils of the alpine ecosystems in the Qinghai-Tibetan Plateau (including the Qilian Mountains) were mostly nitrogen-limited. Furthermore, just as in the soils of the boreal forest and arctic tundra, $95 \%$ of the nitrogen in this region's soils is present as organic nitrogen and nitrogen in senescent leaves, sources that are more difficult for plants to absorb (Xu et al., 2006; Courtney and Harrington, 2010; Jiang et al., 2012). Therefore, the study of the diversity of nitrogen-fixing bacterial communities and the factors that impact them are of great importance in nitrogen-limited regions such as the southern Qilian Mountains.

We hypothesise that the nitrogen-fixing bacterial communities beneath vegetative cover of different plant species and life forms may be distinctive. In this study, we examined the nitrogen-fixing bacterial communities associated with $P o$ tentilla parvifolia shrubland and Carex alrofusca meadow, which are the dominant vegetation types in the southern Qilian Mountains. The objectives of the study were (1) to detect the differences in nifH gene diversity and abundance in the shrubland and meadow soils, and (2) to determine the environmental factors that affect nifH gene diversity and abundance.

\section{Materials and methods}

\subsection{Study site and soil sampling}

Heihe River basin lies between $37^{\circ} 41^{\prime}$ and $42^{\circ} 42^{\prime} \mathrm{N}$ and $96^{\circ} 42^{\prime}$ and $102^{\circ} 00^{\prime} \mathrm{E}$ and has a drainage area of $14.29 \times 10^{4} \mathrm{~km}^{2}$. The upper reaches of the Heihe River basin are located on the north slopes of the Qilian Mountains (Li et al., 2001). The precipitation in the Qilian Mountains is concentrated during the summer and tends to decrease from east to west while increasing with altitude, from approximately $200 \mathrm{~mm}$ at low altitudes to $600 \mathrm{~mm}$ at high altitudes. The vegetation types of the region are varied and include from low to high altitudes - desert steppe, drying shrubbery grassland, forest grassland, subalpine shrubbery meadow and alpine cold-and-desert meadow (Wang et al., 2009).

In the present study, six sampling sites along an altitude gradient of 3086 to $4130 \mathrm{~m}$ in one typical valley (Binggou) were selected, and soil sampling was conducted between 10 and 11 August 2011. We placed three quadrats within each study site, and five soil samples were collected from each quadrat and pooled, for a total of three samples from each site. The samples were cooled on ice until they were delivered to the laboratory and further processed. Sample site locations, soil physicochemical properties and vegetation information are provided in Table 1.

\subsection{Biogeochemical properties of the soil}

Soil water content, $\mathrm{pH}$, organic $\mathrm{C}$ and total $\mathrm{N}$ were measured by previously described methods (Liu et al., 2012). The soil organic matter was determined by loss on ignition, while available $\mathrm{P}$ and $\mathrm{K}$ were measured following $\mathrm{NH}_{4} \mathrm{OAc}$ extraction as described previously (Qian et al., 1994). The salt content was calculated as the sum of cations and anions.

\subsection{PCR amplification of the nifH gene fragment}

We performed three DNA extractions per site from the three composite samples using the PowerSoil DNA Isolation Kit (MoBio Inc., Carlsbad, CA, USA) according to the manufacturer's instructions. The three DNA extractions were then pooled for polymerase chain reaction (PCR).

The selected primers nifH-F and nifH-R (5'AAAGG(C/T)GG(A/T)ATCGG(C/T)AA(A/G)TC CACCAC- $3^{\prime}$ and $5^{\prime}$-TTGTT(G/C)GC(G/C)GC(A/G)TACAT(G/C)GCCATCAT-3') were used to amplify $457 \mathrm{bp}$ nifH gene fragments from the soil DNA; these primers targeted a wide range of nitrogen-fixing bacteria, including the Proteobacteria (Rösch et al., 2002; Gaby and Buckley, 2012). PCR was conducted using a Sure Cycler 8800 (Agilent Technologies). The PCR amplification conditions were set exactly as described previously (Rösch et al., 2002). To avoid potential sample biases and to obtain enough PCR products for cloning, three replicate amplifications were conducted for each sample. 
Table 1. Sample site locations, soil physicochemical properties, vegetation information and characteristics of the clone libraries.

\begin{tabular}{|c|c|c|c|c|c|c|c|}
\hline & & Site 1 & Site 2 & Site 3 & Site 4 & Site 5 & Site 6 \\
\hline \multirow{3}{*}{$\begin{array}{l}\text { Sample site } \\
\text { locations }\end{array}$} & Latitude & $38^{\circ} 07^{\prime} 60 \mathrm{~N}$ & $38^{\circ} 03^{\prime} 51 \mathrm{~N}$ & $38^{\circ} 03^{\prime} 60 \mathrm{~N}$ & $38^{\circ} 03^{\prime} 54 \mathrm{~N}$ & $38^{\circ} 01^{\prime} 48 \mathrm{~N}$ & $38^{\circ} 00^{\prime} 57 \mathrm{~N}$ \\
\hline & Longitude & $100^{\circ} 10^{\prime} 29 \mathrm{E}$ & $100^{\circ} 15^{\prime} 56 \mathrm{E}$ & $100^{\circ} 12^{\prime} 57 \mathrm{E}$ & $100^{\circ} 12^{\prime} 52 \mathrm{E}$ & $100^{\circ} 13^{\prime} 60 \mathrm{E}$ & $100^{\circ} 14^{\prime} 12 \mathrm{E}$ \\
\hline & Altitude $\left(\mathrm{m}^{-1}\right)$ & 3086 & 3205 & 3377 & 3602 & 3802 & 4130 \\
\hline \multirow{8}{*}{$\begin{array}{l}\text { Soil } \\
\text { physicochemical } \\
\text { properties }\end{array}$} & TOC $\left(\mathrm{g} \mathrm{kg}^{-1}\right)$ & 163.85 & 132.48 & 105.6 & 134.06 & 157.12 & 16.85 \\
\hline & $\mathrm{TN}\left(\mathrm{g} \mathrm{kg}^{-1}\right)$ & 5.6 & 9.5 & 10.1 & 1.9 & 7.9 & 5.4 \\
\hline & $\mathrm{OM}\left(\mathrm{g} \mathrm{kg}^{-1}\right)$ & 282.47 & 228.39 & 182.05 & 231.11 & 270.87 & 29.26 \\
\hline & $\mathrm{pH}$ & 6.89 & 6.97 & 7.71 & 6.43 & 6.36 & 6.61 \\
\hline & Soil water content $\left(\mathrm{g} \mathrm{kg}^{-1}\right)$ & 406.8 & 518.7 & 233.5 & 362.2 & 489.5 & 337.5 \\
\hline & Available $\mathrm{P}\left(\mathrm{mg} \mathrm{kg}^{-1}\right)$ & 8.14 & 4.26 & 7.30 & 3.24 & 2.08 & 2.82 \\
\hline & Available $\mathrm{K}\left(\mathrm{mg} \mathrm{kg}^{-1}\right)$ & 82.7 & 178.2 & 153.3 & 108.2 & 88.0 & 70.1 \\
\hline & Salt $\left(\mathrm{g} \mathrm{kg}^{-1}\right)$ & 8.93 & 14.88 & 9.15 & 9.12 & 8.36 & 5.88 \\
\hline \multirow{5}{*}{$\begin{array}{l}\text { Vegetation } \\
\text { information }\end{array}$} & $H_{\text {vegetation }}$ & 1.940 & 1.305 & 1.157 & 1.847 & 1.587 & 2.010 \\
\hline & $\begin{array}{l}\text { Aboveground biomass } \\
\mathrm{g}\left(\mathrm{m}^{2}\right)^{-1}\end{array}$ & 212.50 & 362.50 & 517.50 & 312.50 & 135.00 & 145.00 \\
\hline & $\begin{array}{l}\text { Underground biomass } \\
\mathrm{g}\left(0.1 \mathrm{~m}^{3}\right)^{-1}\end{array}$ & 1734.0 & 3740.00 & 1853.0 & 1037.00 & 1785.00 & 51.00 \\
\hline & Cover degree $\%$ & 60 & 65 & 92 & 70 & 70 & 15 \\
\hline & $\begin{array}{l}\text { Dominant plant } \\
\text { community }\end{array}$ & $\begin{array}{l}\text { Potentilla parvifolia } \\
\text { shrubland }\end{array}$ & $\begin{array}{l}\text { Potentilla parvifolia } \\
\text { shrubland }\end{array}$ & $\begin{array}{l}\text { Potentilla parvifolia } \\
\text { shrubland }\end{array}$ & $\begin{array}{l}\text { Carex alrofusca } \\
\text { meadow }\end{array}$ & $\begin{array}{l}\text { Carex alrofusca } \\
\text { meadow }\end{array}$ & $\begin{array}{l}\text { Carex alrofusca } \\
\text { meadow }\end{array}$ \\
\hline \multirow{4}{*}{$\begin{array}{l}\text { Characteristics } \\
\text { of the clone } \\
\text { libraries }\end{array}$} & $n$ & 3 & 1 & 1 & 3 & 1 & 5 \\
\hline & $N$ & 17 & 20 & 24 & 45 & 76 & 74 \\
\hline & Coverage $\%$ & 82.35 & 95 & 95.83 & 93.33 & 98.68 & 93.24 \\
\hline & OTUs & 6 & 6 & 6 & 11 & 11 & 22 \\
\hline
\end{tabular}

\subsection{Cloning and restriction fragment length polymorphism (RFLP) analysis}

The PCR products were purified using a TIANquick Midi Purification Kit (Tiangen Biotech Co., Ltd., Beijing) and cloned into the pMD 18-T vector (Takara Biotech Co., Ltd., Dalian) according to the manufacturer's protocols. The plasmids were transformed into the competent $E$. coli $D H 5 \alpha$ by the heat shock method, as described by Huff et al. (1990). All of the white colonies were picked and screened for the desired gene inserts, which were detected using the specific primers M13F/M13R for the pMD 18-T vector.

Unique clones were detected using RFLP analysis with two restriction enzymes (Alu I and Hae III). Enzyme digestion and gel electrophoresis of the digested products were performed as described previously (Zhou et al., 2002).

\subsection{Sequencing and phylogenetic analysis}

To understand the phylogenetic diversity of the samples, representative nifH clones of the unique RFLP patterns as determined by cluster analysis were sequenced. A total of 62 nifH clones were sequenced. The nucleotide acid identities of the sequenced clones were compared to each other using ContigExpress software and to the GenBank database using BLAST software in order to obtain the clone from each pattern that was most similar to an existing nifH sequence in the database. The BLAST analyses were conducted on 12 January 2013.

A phylogenetic tree was constructed based on a comparison of the nifH sequences from the samples of the shrubland and meadow soils and their closest phylogenetic rel- atives. The alignment was performed using ClustalX (version 1.8). The phylogenetic distances (distance options according to the Jukes-Cantor model) and clustering from the neighbour-joining method were determined using bootstrap values based on 1000 replications with Mega (version 4.0) software (Jukes and Cantor, 1969; Saitou and Nei, 1987; Kumar et al., 2001; Zhang et al., 2012). The GenBank accession numbers of the nifH sequences are KC445661-KC445735.

Nitrogen-free medium (NFM) was selected as the selective medium for studying the cultured nitrogen-fixing bacteria, as several previous studies had proved this medium to be most selective, least susceptible to overgrowth by other bacteria that were not nitrogen-fixing and most reproducible, allowing for the growth of a broad diversity of nitrogen-fixing bacteria (Beauchamp et al., 1991, 2006). The colony-forming units (CFUs) were determined based on plate counts. Diversity of the cultured nitrogen-fixing bacteria from each sample was calculated based on RFLP analysis of 16S rDNA using the previously described method (Dunbar et al., 1999). 16S rDNA sequence analysis was chosen for the identification of the isolates (data not shown). We anticipated that we would find nifH genes from the isolates in our samples. These isolates were characterised as nitrogen fixers by previous studies (Cacciari et al., 1979; Lifshitz et al., 1986; Videira et al., 2009).

\subsection{Quantitative PCR analysis of nifH gene}

The abundance of nifH gene copies in the shrubland and meadow soils was determined using Q-PCR with SYBR Green. The primer sequences used to amplify fragments of the nifH gene were $n i f H-\mathrm{F}$ and $n i f H-\mathrm{R}$. The standards for 
measuring the quantity of the nifH gene were developed from a clone with the correct insert. A plasmid DNA preparation was obtained from the clone using a Qiagen Miniprep kit (Qiagen, Germantown, MD, USA). The copy number of the target gene in a nanogram of plasmid DNA was determined, and a serial dilution was then prepared, ranging from $10^{8}$ to $10^{2}$ copies. This set of dilutions was used for the standard curve.

Q-PCR was conducted in triplicate for both the standard and the samples. The fluorescence signal was used to calculate the $C_{\mathrm{T}}$ (cycle threshold) values using the thermocycler software for each machine. The copy number of the nifH gene per gram of soil was determined through comparison to the standard curve of $10^{2} \sim 10^{8}$ gene copies in the assay. The standard curve of Q-PCR was $Y=-3.205 \times \log (X)+36.78$, based on the average of the triplicate data; the $R^{2}$ value of the curve was 0.996, and the efficiency of Q-PCR was $105.1 \%$.

Q-PCR of nifH was performed in a $10 \mu \mathrm{L}$ reaction mixture that contained $5 \mu \mathrm{L}$ of SYBR Green PCR master mix $(2 \times)$ (Applied Biosystems, Foster City, CA, US), $0.4 \mu \mathrm{L}$ of each primer $(10 \mu \mathrm{M}), 3.2 \mu \mathrm{L}$ of sterile ultrapure water and $1 \mu \mathrm{L}$ of extracted DNA ( 10-25 ng). Amplification was performed using a Stratagene MX3005. The Q-PCR cycling parameters were $30 \mathrm{~s}$ at $95^{\circ} \mathrm{C}, 40$ cycles of $95^{\circ} \mathrm{C}$ for $5 \mathrm{~s}, 55^{\circ} \mathrm{C}$ for $30 \mathrm{~s}$ and $72^{\circ} \mathrm{C}$ for $30 \mathrm{~s}$, a dissociation stage of $95^{\circ} \mathrm{C}$ for $30 \mathrm{~s}$ and $55^{\circ} \mathrm{C}$ for $30 \mathrm{~s}$ and a final ramp-up to $95^{\circ} \mathrm{C}$. Melting curve analysis was employed to confirm the specificity of the QPCR technique.

\subsection{Statistical methods}

The nifH operational taxonomic unit (OTU) calculation was based on RFLP patterns. Clones with same RFLP pattern were clustered into one OTU (Jungblut and Neilan, 2010; Strassert et al., 2012). The coverage of each clone library was calculated using Eq. (1), where $n$ is the number of OTUs containing unique clones and $N$ is the total number of clones (Table 1). According to the genotypes of the OTUs and the number of clones for each OTU based on the RFLP-clone library approach, the Shannon-Wiener diversity index of the nifH gene was calculated using Eq. (2), where $\mathrm{n}_{i}$ is number of clones of the $i$-th OTU, and $p_{i}$ indicates the proportion of clones of the $i$-th OTU in the total clone library of the sample (Duc et al., 2009).

Coverage $=[1-(n / N)] \times 100 \% \quad($ Huang et al., 2011)

$H=-\sum p_{i} \ln p_{i}\left(p_{i}=n_{i} / N\right) \quad$ (Duc et al., 2009)

In order to cluster or separate the samples based on the characteristics of the nitrogen-fixing bacterial communities, hierarchical cluster analyses were performed using the SPSS statistical package (version 16.0, SPSS Inc., Chicago, IL, USA) with the average-linkage-between-groups methods (Huang et al., 2011; Nonnoi et al., 2012).
Redundancy analysis (RDA) was performed to analyse the characteristics of the nitrogen-fixing bacterial communities in combination with the environmental parameters using the CANOCO program for Windows (version 4.5) (Braak and Smilauer, 1998; Zumsteg et al., 2012); this approach identifies potential or indirect environmental gradients that explain changes in community characteristics. Because the characteristics of the nitrogen-fixing bacterial communities exhibited linear, rather than unimodal, responses to the environmental variables, RDA was employed instead of CCA to analyse the correlations between the characteristics of the nitrogen-fixing bacterial communities and the environmental factors.

The rooted phylogenetic tree created with Mega (version 4.0) was analysed using the Unifrac interface (http://bmf.colorado.edu/unifrac/), which provides a suite of tools for the comparison of nitrogen-fixing bacterial communities. Unifrac tests the significance of the differences between environments in terms of the phylogenetic branch, which is unique to each environment. The $P$ test uses the phylogenetic tree to test whether the two environments are significantly different using parsimony. The Unifrac and $P$-test significance values were corrected using the Bonferroni correction for multiple comparisons (Castro et al., 2010). Lineage-specific analysis was performed to determine whether the community differences were concentrated within particular lineages of the phylogenetic tree by applying the $G$ test for goodness of fit to all clades (subtrees) within the tree at a defined distance $(0.0433)$ from the tree root (Lozupone et al., 2006).

\section{Results}

\subsection{Characteristics of nitrogen-fixing bacterial communities}

The colony-forming units (CFUs) and diversity indices ( $\left.H_{\text {cultured }}\right)$ of the nitrogen-fixing bacterial communities are shown in Fig. 1. The CFUs ranged from 0.97 to 12.78 $\left(10^{6} \mathrm{~g}^{-1}\right.$ wet soil), while $H_{\text {cultured }}$ ranged from 0.2 to 1.4 ; both of these measures were lower in the meadow soil than in the shrubland soil along the altitude gradient. The nitrogenfixing bacterial community in the meadow soil showed a higher Shannon-Wiener diversity index $\left(H_{\text {nif }}\right)$ than that of the shrubland soil, and $H_{\text {nif }}$ increased from 1.5 to 2.8 with elevating altitude. Figure 2 shows that the abundance of the nifH gene (number of copies) was higher in the shrubland soil than in the meadow soil and ranged from 0.4 to 6.9 $\left(10^{7} \mathrm{~g}^{-1}\right.$ wet soil). A melting curve with a single melting peak was detected at $91.00^{\circ}$, and no primer dimers or other unspecific PCR products were amplified, indicating that the result of a single amplicon in the Q-PCR analysis was accurate (Fig. 6). 
Table 2. Nitrogen-fixing bacterial community composition in the shrubland and meadow soils.

\begin{tabular}{|c|c|c|c|c|c|c|c|}
\hline \multirow[b]{2}{*}{ Shrubland soil } & \multirow{2}{*}{$\begin{array}{l}\text { Phylum } \\
\alpha \text {-Proteobacteria }\end{array}$} & \multirow{2}{*}{$\begin{array}{l}\text { Genera } \\
\text { Bradyrhizobium } \star^{\mathrm{a}}\end{array}$} & \multirow{2}{*}{$\frac{\text { Relative abundance } / \%}{45}$} & \multicolumn{4}{|c|}{ Assignment } \\
\hline & & & & Site & 1 & 2 & 3 \\
\hline & $\alpha$-Proteobacteria & Sinorhizobium & 10 & Site & 1 & & \\
\hline & $\alpha$-Proteobacteria & Azospirillum $^{\mathrm{b}}$ & 1.67 & Site & 1 & & \\
\hline & $\beta$-Proteobacteria & Burkholderia & 15 & Site & 1 & & \\
\hline & $\beta$-Proteobacteria & Dechloromonas & 16.67 & Site & & 2 & \\
\hline & $\beta$-Proteobacteria & Herbaspirillum & 11.67 & Site & & 2 & \\
\hline \multirow[t]{13}{*}{ Meadow soil } & $\alpha$-Proteobacteria & Bradyrhizobium $\star$ & 49.73 & Site & 4 & 5 & 6 \\
\hline & $\alpha$-Proteobacteria & Sinorhizobium & 0.53 & Site & 4 & & \\
\hline & $\alpha$-Proteobacteria & Mesorhizobium & 6.42 & Site & & 5 & \\
\hline & $\alpha$-Proteobacteria & Ensifer & 2.14 & Site & & & 6 \\
\hline & $\alpha$-Proteobacteria & Methylocella & 0.53 & Site & & & 6 \\
\hline & $\beta$-Proteobacteria & Burkholderia & 11.76 & Site & 4 & & 6 \\
\hline & $\beta$-Proteobacteria & Dechloromonas & 1.60 & Site & 4 & & 6 \\
\hline & $\beta$-Proteobacteria & Herbaspirillum & 1.60 & Site & 4 & & \\
\hline & $\beta$-Proteobacteria & Derxia & 5.34 & Site & 4 & & \\
\hline & $\gamma$-Proteobacteria & Thiocapsa & 2.34 & Site & 4 & 5 & 6 \\
\hline & $\gamma$-Proteobacteria & Ectothiorhodospira & 8.56 & Site & 4 & & 6 \\
\hline & $\gamma$-Proteobacteria & Klebsiella & 8.56 & Site & & 5 & 6 \\
\hline & $\gamma$-Proteobacteria & Pseudomonas & 1.07 & Site & & & 6 \\
\hline
\end{tabular}

a The black star indicates the predominant genus in shrubland and meadow soils.

$\mathrm{b}$ The generic names in bold indicate those genera unique to each soil.
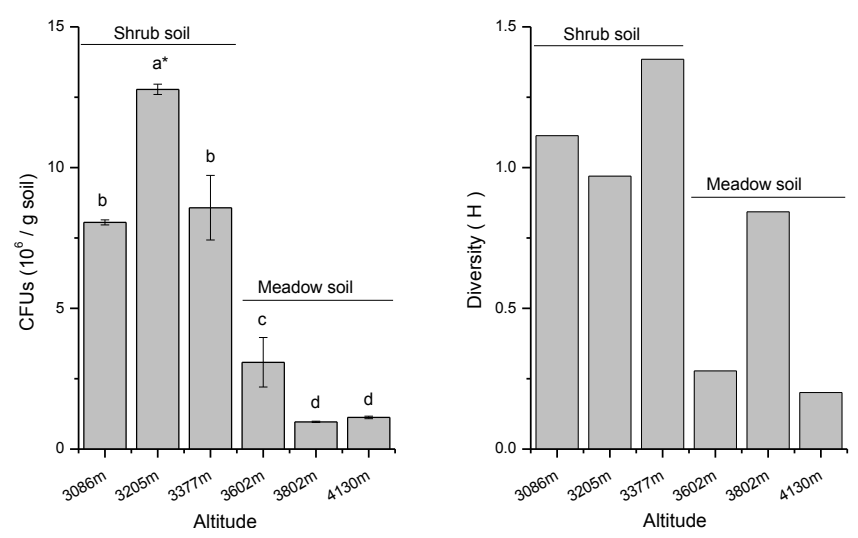

Fig. 1. CFUs and diversity indices of cultured nitrogen-fixing bacteria $(*$ the letters represent confidence levels above $95 \%)$.

The cluster analysis of the nitrogen-fixing bacterial communities in the shrubland and meadow soil in terms of their characteristics (CFUs, $H_{\text {cultured, }}$, number of copies and $H_{\text {nif }}$ ) indicated that the nitrogen-fixing bacterial communities from each environment clustered together (Fig. 3). In other words, the nitrogen-fixing bacterial communities derived from the same soil type (shrubland soil or meadow soil) were more similar to each other than to communities from the other soil type.
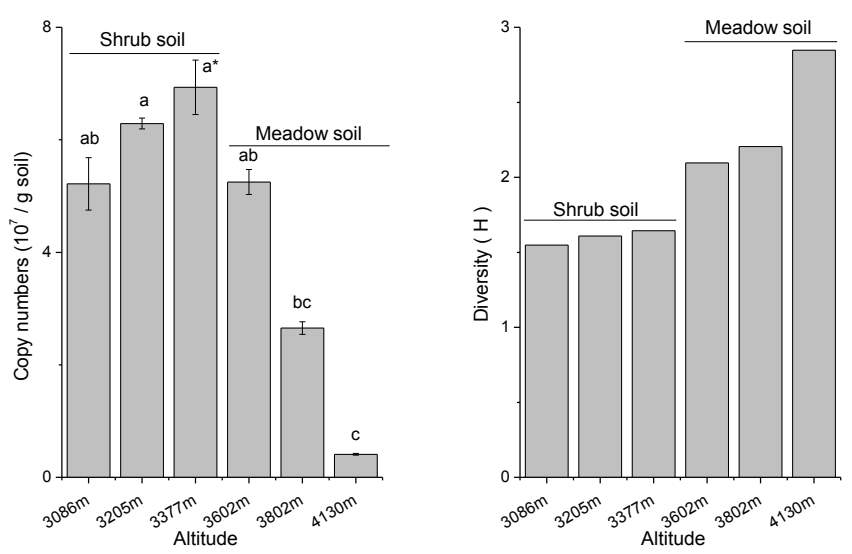

Fig. 2. Copy numbers and diversity indices of the nifH gene $(*$ the letters represent confidence levels above $95 \%$ ).

\subsection{Phylogeny of nitrogen-fixing bacteria}

Figure 4 reveals that while many of the nif $H$ gene sequences had close similarity to those of identified nitrogen-fixing bacteria, a number of the nifH sequences clustered without any corresponding diazotroph species identified in GenBank. Among the identified nitrogen-fixing bacterial clones, those associated with Bradyrhizobium, Sinorhizobium, Burkholderia, Dechloromonas and Herbaspirillum were found in both the shrubland and meadow soils, and Bradyrhizobium was the dominant genus. Table 2 indicates that Azospirillum was only present in the shrubland soil, while Thiocapsa, 


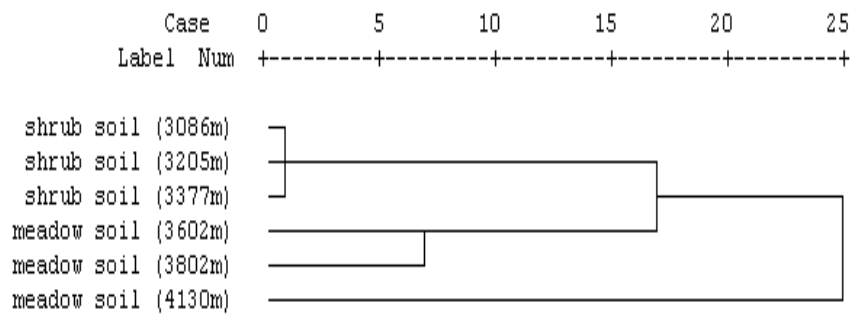

Fig. 3. Hierarchical cluster analysis of the nitrogen-fixing bacterial communities in the study region. Euclidean distance was selected as the interval.

Table 3. The significance tests of the microbial communities.

\begin{tabular}{llll}
\hline & $\begin{array}{l}\text { Unifrac } \\
\text { significance } \\
\text { test }\end{array}$ & $P$ test & $\begin{array}{l}\text { Lineage-specific } \\
\text { analysis }\end{array}$ \\
\hline$P$ values * & 0.03 & $\leq 0.01$ & $\begin{array}{l}\text { Lineage I: }<0.001 \\
\text { Lineage II: }<0.001\end{array}$ \\
& & Lineage III: 0.02 \\
& & Lineage IV: $<0.001$ \\
& & Lineage $\mathrm{V}:<0.001$ \\
\hline
\end{tabular}

*<0.001: highly significant; 0.001-0.01: significant; 0.01-0.05: marginally significant.

Derxia, Ectothiorhodospira, Mesorhizobium, Klebsiella, Ensifer, Methylocella and Pseudomonas were detected only in the meadow soil. All of the identified nitrogen-fixing bacterial clones belonged to the Proteobacteria. The Unifrac significance $(P=0.03)$ and $P$-test significance $(P=0.01)$ values all indicated that the nitrogen-fixing bacterial communities were significantly different between the shrubland and meadow soils (Table 3). The phylogenetic tree was divided into five lineages (lineages I-V): lineage I, II and III mainly contained nifH sequences obtained from the meadow soil, while lineage IV was mainly composed of nifH sequences obtained from the shrubland soil (Fig. 4). The $P$ values of each lineage indicated that the distributions of the lineages between the two environments were different (Table 3).

\subsection{Correlations between characteristics of the nitrogen-fixing bacterial communities and environmental factors}

The results of the RDA indicated that $\mathrm{PC} 1$ explains more than $90 \%$ of the variance, while PC2 explains less than $10 \%$. Therefore, the first axis accounted for a valuable part of the variance, while the second axis did not. Underground biomass had a significant positive correlation with the first axis and strongly influenced the bacterial communities in shrubland soil, while available $\mathrm{K}$ had a strong influence on the communities in meadow soil (Fig. 5). In the shrubland soil, the nifH gene diversity and copy number were primarily correlated with aboveground biomass. The CFUs of the cul-

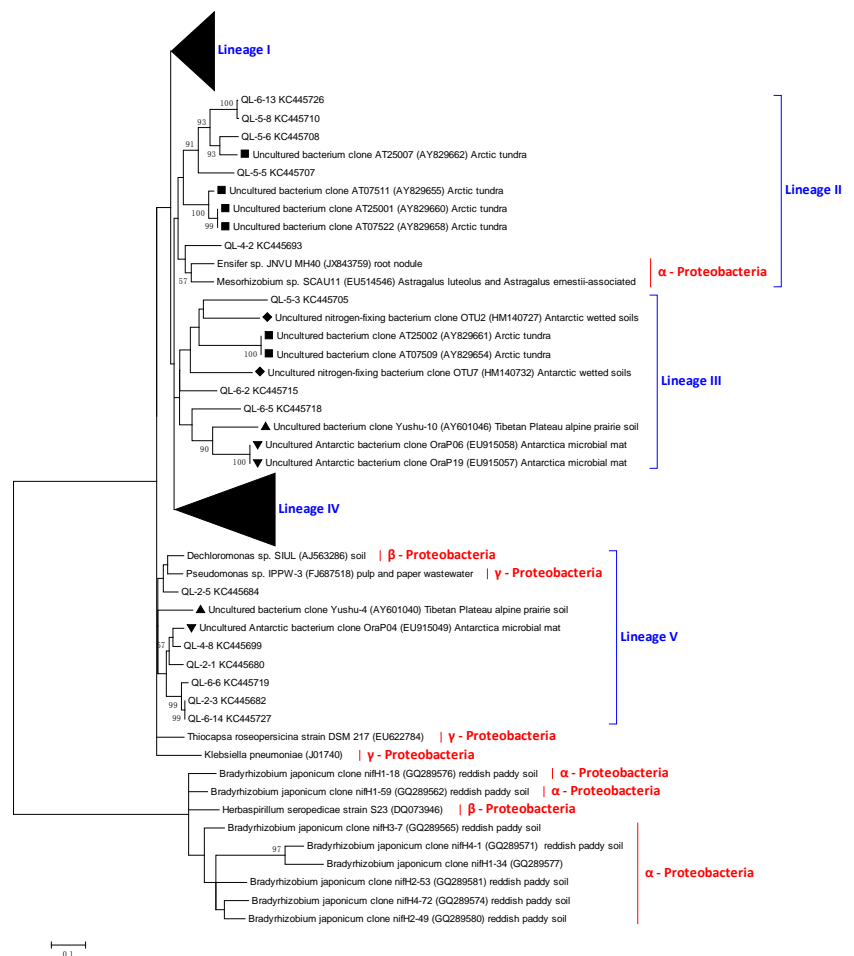

Fig. 4a. Phylogenetic tree based on a comparison of the nifH sequences determined from the samples of shrubland soil (18 sequences) and meadow soil (44 sequences) and their closest phylogenetic relatives (30 sequences), which were obtained using BLAST. A number of other nifH gene sequences (50) obtained from the Tibetan Plateau, the Antarctic and the Arctic were included to construct a robust phylogenetic tree. The alignment was performed using ClustalX (version 1.8). Phylogenetic distances (distance options according to the Jukes-Cantor model) and clustering with the neighbour-joining method were determined using bootstrap values based on 1000 replications. Bootstrap values $>50$ are shown. Clones from this study are designated with the prefix QL, followed by the soil code (1-6) and the clone code. The accession number follows each clone. Solid circles, squares, triangles, rhombuses and inverted triangles indicate those nifH gene sequences obtained from high Arctic dwarf shrubland soil, Arctic tundra, Tibetan Plateau alpine prairie soil, Antarctic wetted soil and the Antarctic microbial mat, respectively. The scale bar indicates nucleotide substitution per site.

tured nitrogen-fixing bacteria were affected by underground biomass. Altitude affected the diversity of the nifH gene in the meadow soil, where copy number was primarily correlated with soil-available K. The cultured nitrogen-fixing bacterial diversity was affected by soil water content, while CFUs were correlated with aboveground biomass.

\section{Discussion}

The Shannon-Wiener diversity index of the nifH gene in the southern Qilian Mountains was 2.85, which is higher 


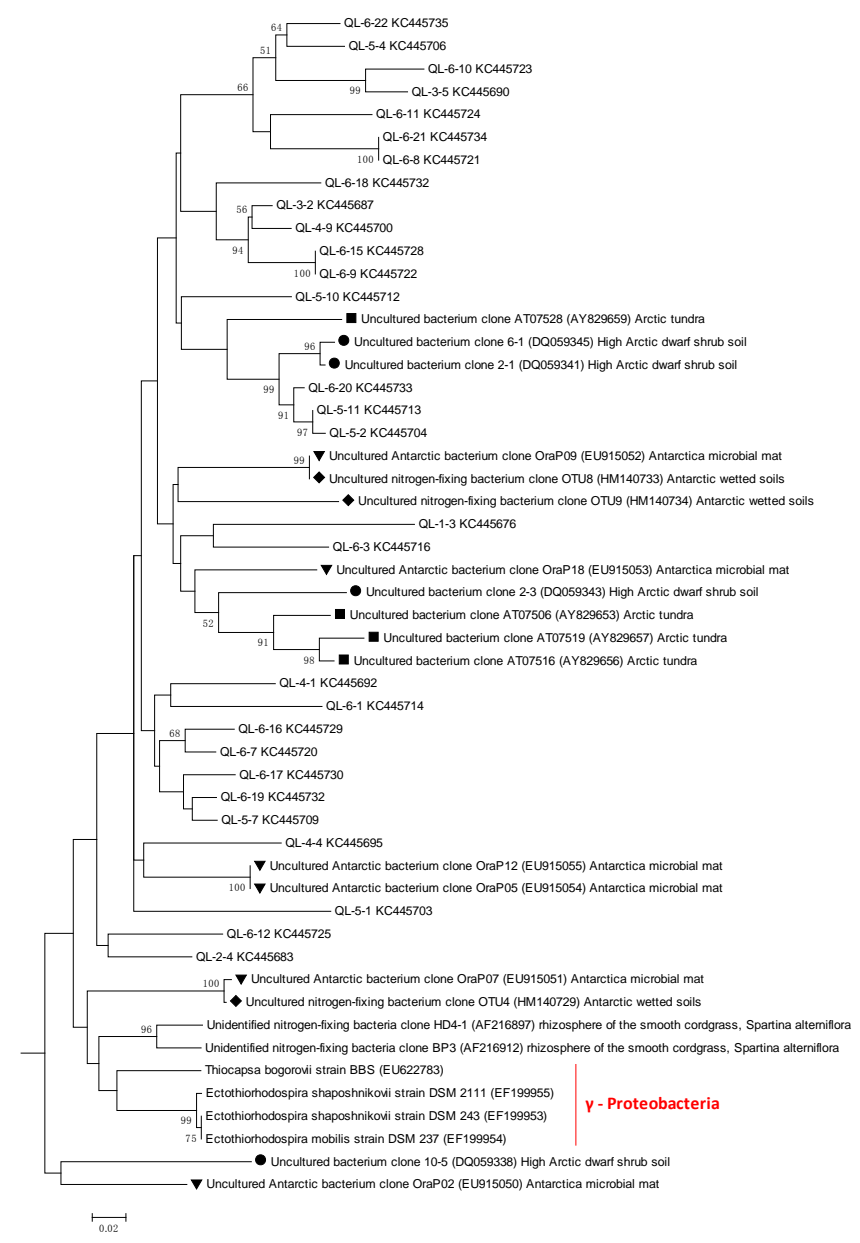

Fig. 4b. The subtree displays the phylogeny of lineage I.

than that observed in other cold regions across the world, such as Antarctic soil (Jungblut and Neilan, 2010; Niederberger et al., 2012), Arctic soil (Deslippe and Egger, 2006; Izquierdo and Nüsslein, 2006) and Tibetan Plateau alpine soil (Zhang et al., 2006). The abundance of the nifH gene was $10^{7}$ copies $^{-1}$ soil (Fig. 2), a value slightly higher than that of previously published results. Niederberger et al. (2012) found that proteobacterial nifH genes ranged from $10^{4}$ to $10^{5}$ copies g $^{-1}$ soil in Antarctic wetted soil. Coelho et al. (2009) observed $10^{5}$ to $10^{7}$ copies $^{-1}$ soil of nifH genes in Brazilian farmland soil. The high diversity and abundance of the nifH gene in the southern Qilian Mountains suggests that the soil $\mathrm{pH}$ in the southern Qilian Mountains is close to 7 (Table 4), which is the optimum for the majority of nitrogen-fixing bacteria (Tamm, 1991). Furthermore, the primers used in this study, nifH-F and nifH-R, targeted a wide range of nitrogen-fixing bacteria and were different from those used in other studies (Rösch et al., 2002; as reviewed in Gaby and Buckley, 2012). In the southern Qilian Mountains, the Shannon diversity index of the nitrogen-fixing bacteria in the shrubland soil was lower than

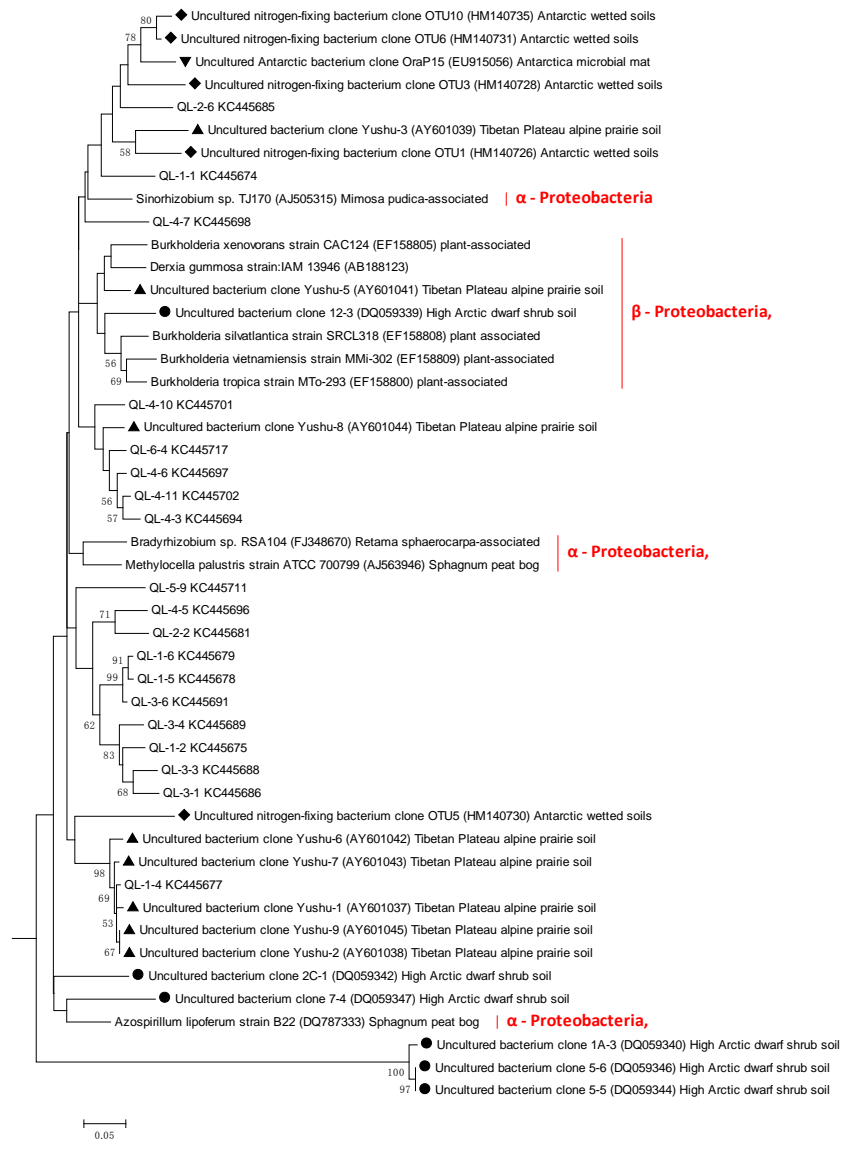

Fig. 4c. The subtree displays the phylogeny of lineage IV.

that of the bacteria in the meadow soils. Hsu and Buckley (2009) have found that higher levels of vegetation biomass reduce nitrogen-fixing bacterial diversity, and a higher vegetation biomass was observed in the shrubland soil than in the meadow soil (Table 1).

Five major clusters with homology to nifH have been described. Cluster I is composed entirely of nifH genes from most of the Proteobacteria, all of the Cyanobacteria and certain Firmicutes (Paenibacillus) and Actinobacteria (Frankia). Cluster II contains sequences belonging to certain methanogenic Archaea. Cluster III is dominated by nifH sequences from the anaerobic members of the Bacteria and Archaea, including spirochetes, methanogens, acetogens, sulfate-reducing bacteria, green sulfur bacteria and clostridia. Clusters IV and V are composed of nifH paralogues that are not involved in nitrogen fixation and include genes of various functions (Zehr et al., 2003; Palacios and Newton, 2005). All of the nifH sequences identified in this study belonged to the Proteobacteria and fell into cluster I, a result consistent with those of previous studies (Fig. 4). Gaby and Buckley (2011) concluded that the most dominant OTUs of nifH belonged to either the Proteobacteria or the Cyanobacteria. Chowdhury et al. (2009) demonstrated that 

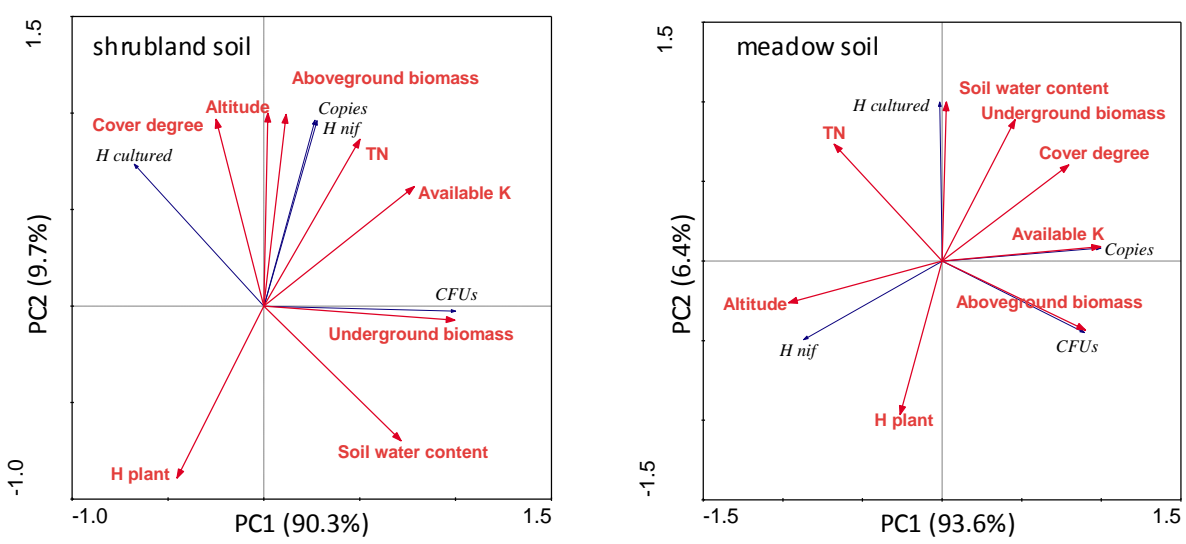

Fig. 5. RDA analysis between the nitrogen-fixing bacterial characteristics and environmental factors. The RDA plot was constructed with the biplots method and joint plots between the species and environmental variables based on the linear model using CanoDraw. The red arrows and words represent the environmental factors, while the blue arrows indicate community characteristics.

Table 4. Nitrogen-fixing bacterial communities in different regions of the world.

\begin{tabular}{|c|c|c|c|c|c|}
\hline $\begin{array}{l}\text { Study } \\
\text { regions }\end{array}$ & $\begin{array}{l}\text { Average } \\
\text { soil pH }\end{array}$ & $\begin{array}{l}\text { Shannon } \\
\text { index }\end{array}$ & Dominant phyla & $\begin{array}{l}\text { Predominant } \\
\text { genera }\end{array}$ & Reference \\
\hline $\begin{array}{l}\text { Antarctica } \\
\text { wetted soil }\end{array}$ & 8.48 & 2.60 & $\begin{array}{l}\alpha \text {-Proteobacteria, } \\
\beta \text {-Proteobacteria, } \\
\gamma \text {-Proteobacteria, } \\
\delta \text {-Proteobacteria, } \\
\text { Cyanobacteria }\end{array}$ & Geobacter & Niederberger et al. (2012) \\
\hline $\begin{array}{l}\text { Antarctica } \\
\text { microbial mat }\end{array}$ & 9.90 & 2.11 & $\begin{array}{l}\beta \text {-Proteobacteria, } \\
\gamma \text {-Proteobacteria, } \\
\delta \text {-Proteobacteria, } \\
\text { Firmicutes, } \\
\text { Spirochaetes, } \\
\text { Cyanobacteria, } \\
\text { Verrucomicrobia, } \\
\text { Unidentified cluster }\end{array}$ & Azotobacter & Jungblut et al. (2010) \\
\hline $\begin{array}{l}\text { Canadian } \\
\text { High Arctic } \\
\text { shrubland soil }\end{array}$ & ND & 2.04 & $\begin{array}{l}\alpha \text {-Proteobacteria, } \\
\beta \text {-Proteobacteria, } \\
\gamma \text {-Proteobacteria, } \\
\text { Firmicutes, } \\
\text { Unidentified cluster }\end{array}$ & Rhodopseudomonas & Deslippe et al. (2006) \\
\hline $\begin{array}{l}\text { Arctic } \\
\text { tundra soil }\end{array}$ & 6.70 & 1.97 & $\begin{array}{l}\alpha \text {-Proteobacteria, } \\
\gamma \text {-Proteobacteria, } \\
\delta \text {-Proteobacteria, } \\
\text { Cyanobacteria, } \\
\text { Spirochaetae, } \\
\text { Unidentified cluster }\end{array}$ & Rhodopseudomonas & Izquierdo et al. (2006) \\
\hline $\begin{array}{l}\text { Tibetan Plateau } \\
\text { alpine prairie } \\
\text { soil }\end{array}$ & 7.43 & 2.09 & $\begin{array}{l}\alpha \text {-Proteobacteria, } \\
\beta \text {-Proteobacteria, } \\
\gamma \text {-Proteobacteria, } \\
\delta \text {-Proteobacteria, } \\
\text { Unidentified cluster }\end{array}$ & Methylocella & Zhang et al. (2006) \\
\hline $\begin{array}{l}\text { Qilian } \\
\text { Mountains } \\
\text { shrubland and } \\
\text { meadow soils }\end{array}$ & 7.04 & 2.85 & $\begin{array}{l}\alpha \text {-Proteobacteria, } \\
\beta \text {-Proteobacteria, } \\
\gamma \text {-Proteobacteria, } \\
\text { Unidentified cluster }\end{array}$ & Bradyrhizobium & This study \\
\hline
\end{tabular}




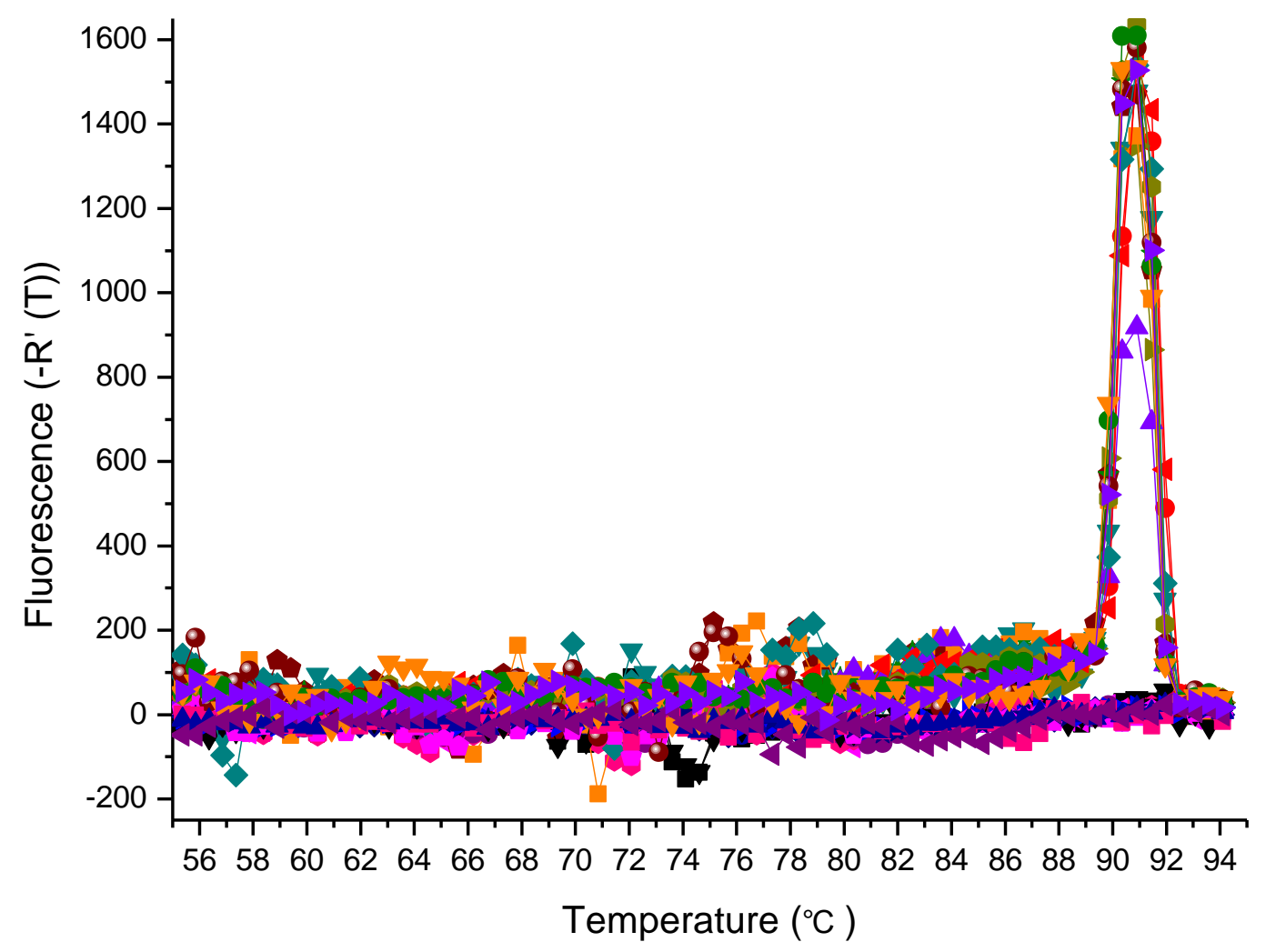

Fig. 6. Melting curve of quantitative PCR.

the nifH clone library from the rhizosphere soil and roots of Lasiurus sindicus grass showed a predominance of Proteobacteria. However, the predominant genera in different extreme environments are distinct (Table 4), and Bradyrhizobium is unique to the shrubland and meadow soils of the southern Qilian Mountains. Furthermore, at the genus level, Azospirillum was only detected in the shrubland soil, while Thiocapsa, Derxia, Ectothiorhodospira, Mesorhizobium, Klebsiella, Ensifer, Methylocella and Pseudomonas were only detected in the meadow soil. One possibility is that plants may select for different nitrogen-fixing bacterial communities (Deslippe and Egger, 2006). The dominance of native alpine species (e.g. Potentilla parvifolia and Carex alrofusca) may have controlled the soil carbon dynamics through changes in root colonisation and exudation, which in turn may have resulted in changes to the nitrogen-fixing bacterial community structure (Bardgett et al., 1998; Gros et al., 2004). Lineage-specific analysis, the Unifrac significance test and the $P$ test all indicated that the nitrogen-fixing bacterial communities beneath Potentilla differed from the ones beneath Carex (Table 3). These results suggest that plant species may influence $\mathrm{N}$ cycling by enhancing the fitness of certain nitrogen-fixing taxa.

The cluster analysis showed that soils of the same vegetation type contained similar nitrogen-fixing bacterial commu- nities (Fig. 3), a result consistent with those of previous studies (Berg et al., 2002; Deslippe and Egger, 2006; Garbeva et al., 2008). They concluded that the abundance and composition of bacteria functional groups were plant species dependent. Similar habitats have similar soils, with similar abiotic and biotic contexts, and therefore harbour bacterial communities that display similar characteristics. A cross-system comparison of nifH gene diversity and microbial community structure indicated that the distribution of nitrogen-fixing microorganisms is non-random and can be predicted on the basis of habitat characteristics (Zehr et al., 2003).

In the present study, the phylogenetic tree was divided into five lineages: lineages I, II and III mainly contained nifH sequences obtained from the meadow soil, while lineage IV was mainly composed of nifH sequences obtained from the shrubland soil. This result suggests that Potentilla is highly $\mathrm{N}$ proficient and falls into the conservative category, while Carex is less $\mathrm{N}$ proficient and falls into the extravagant category in terms of N cycling (Yuan et al., 2005; Chapman et al., 2006). As proposed by Chapman et al. (2006), plant species that fall into the conservative category regulate $\mathrm{N}$ cycling more strongly than plant species exhibiting extravagant $\mathrm{N}$ management. Our findings may provide evidence in support of this hypothesis. In the shrubland soil beneath Potentilla, nifH gene diversity and abundance were primar- 
ily correlated with aboveground biomass. Hsu and Buckley (2009) found that the nitrogen-fixing bacterial community structure differed across treatments as a function of vegetation biomass. Lovell et al. (2001) also demonstrated that differences in the nitrogen-fixing bacterial community are closely associated with vegetation biomass. In the meadow soil beneath Carex, the nifH gene diversity was primarily affected by altitude, while abundance was primarily affected by soil-available K. Zhang et al. (2006) found that altitude was one of the key factors influencing the nitrogen-fixing bacterial community in alpine prairie soil. Niederberger et al. (2012) demonstrated that temperature, which is closely correlated to altitude, may be a driving factor in the composition of the nitrogen-fixing bacterial community in Antarctic soil. Soil K concentration has also been identified as a driver of the nifH gene in several environments (Teng et al., 2009; Hayden et al., 2010).

\section{Conclusions}

Our study revealed a high diversity of nitrogen-fixing bacterial communities in the southern Qilian Mountains. The neutral soil $\mathrm{pH}$ of the study region may provide optimum conditions for nitrogen-fixing bacteria and induce higher nifH gene diversity and abundance compared to other arcticalpine sites with lower or higher soil $\mathrm{pH}$. Based on the assessment of the characteristics of the nitrogen-fixing bacterial communities and the phylogenetic analysis, the nitrogenfixing bacterial communities beneath Potentilla were shown to differ from the ones beneath Carex. Furthermore, Potentilla is considered to be a highly $\mathrm{N}$ proficient and falls into the conservative category, while Carex is a less $\mathrm{N}$ proficient and falls into the extravagant category in terms of $\mathrm{N}$ cycling. These results suggest that plant species in combination with distinct soil physicochemical properties may influence $\mathrm{N}$ cycling by enhancing the fitness of certain nitrogen-fixing bacterial taxa. To our knowledge, this study is the first report on the nifH diversity of plant-associated soil microbes in the southern Qilian Mountains.

Acknowledgements. We are grateful to S. W. Li (Lanzhou Jiaotong University, Gansu, China) and lecturer H. N. Gao (Hexi University, Gansu, China) for their professional advice and support. The project is supported by the Key Project of the Chinese Academy of Sciences (no. KZZD-EW-04-05) and the National Natural Science Foundation of China (no. 31070357; 31100365; 91025002).

Edited by: T. Treude

\section{References}

Bardgett, R. D., Wardle, D. A., and Yeates, G. W.: Linking aboveground and below-ground interactions: how plant responses to foliar herbivory influence soil organisms, Soil Biol. Biochem., 30, 1867-1878, doi:10.1016/S0038-0717(98)00069-8, 1998.

Beauchamp, C. J., Kloepper, J. W., Lifshitz, R., Dion, P., and Antoun, H.: Frequent occurrence of the ability to utilize octopine in rhizobacteria, Can. J. Microbiol., 37, 158-164, doi:10.1139/m91-024, 1991.

Beauchamp, C. J., Lévesque, G., Prévost, D., and Chalifour, F.-P.: Isolation of free-living dinitrogen-fixing bacteria and their activity in compost containing de-inking paper sludge, Bioresource Technol., 97, 1002-1011, doi:10.1016/j.biortech.2005.04.041, 2006.

Berg, G., Roskot, N., Steidle, A., Eberl, L., Zock, A., and Smalla, K.: Plant-Dependent Genotypic and Phenotypic Diversity of Antagonistic Rhizobacteria Isolated from Different Verticillium Host Plants, Appl. Environ. Microb., 68, 3328-3338, doi:10.1128/aem.68.7.3328-3338.2002, 2002.

Braak, C. J. F. T. and Smilauer, P.: CANOCO Reference Manual and User's Guide to Canoco for Windows: Software for Canonical Community Ordination (Version 4), Centre for Biometry, Wageningen, 351 pp., 1998.

Bürgmann, H., Meier, S., Bunge, M., Widmer, F., and Zeyer, J.: Effects of model root exudates on structure and activity of a soil diazotroph community, Environ. Microbiol., 7, 1711-1724, doi:10.1111/j.1462-2920.2005.00818.x, 2005.

Cacciari, I., Lippi, D., and Bordeleau, L. M.: Effect of oxygen on batch and continuous cultures of a nitrogen-fixing Arthrobacter sp, Can. J. Microbiol., 25, 746-751, doi:10.1139/m79-108, 1979.

Castro, H. F., Classen, A. T., Austin, E. E., Norby, R. J., and Schadt, C. W.: Soil Microbial Community Responses to Multiple Experimental Climate Change Drivers, Appl. Environ. Microb., 76, 999-1007, doi:10.1128/aem.02874-09, 2010.

Chapman, S. K., Langley, J. A., Hart, S. C., and Koch, G. W.: Plants actively control nitrogen cycling: uncorking the microbial bottleneck, New Phytol., 169, 27-34, doi:10.1111/j.14698137.2005.01571.x, 2006.

Chowdhury, S. P., Schmid, M., Hartmann, A., and Tripathi, A. K.: Diversity of 16S-rRNA and nifH genes derived from rhizosphere soil and roots of an endemic drought tolerant grass, Lasiurus sindicus, Eur. J. Soil Biol. 45, 114-122, doi:10.1016/j.ejsobi.2008.06.005, 2009.

Cleveland, C. and Liptzin, D.: C : N : P stoichiometry in soil: is there a "Redfield ratio" for the microbial biomass?, Biogeochemistry, 85, 235-252, doi:10.1007/s10533-007-9132-0, 2007.

Coelho, M. R. R., Marriel, I. E., Jenkins, S. N., Lanyon, C. V., Seldin, L., and O'Donnell, A. G.: Molecular detection and quantification of nifH gene sequences in the rhizosphere of sorghum (Sorghum bicolor) sown with two levels of nitrogen fertilizer, Appl. Soil Ecol., 42, 48-53, doi:10.1016/j.apsoil.2009.01.010, 2009.

Courtney, R. and Harrington, T.: Assessment of plant-available phosphorus in a fine textured sodic substrate, Ecol. Eng., 36 , 542-547, doi:10.1016/j.ecoleng.2009.12.001, 2010.

Deslippe, J. and Egger, K.: Molecular Diversity of nifH Genes from Bacteria Associated with High Arctic Dwarf Shrubs, Microb. Ecol., 51, 516-525, doi:10.1007/s00248-006-9070-8, 2006.

Duc, L., Noll, M., Meier, B., Bürgmann, H., and Zeyer, J.: High Diversity of Diazotrophs in the Forefield of a Receding Alpine Glacier, Microb. Ecol., 57, 179-190, doi:10.1007/s00248-0089408-5, 2009. 
Dunbar, J., Takala, S., Barns, S. M., Davis, J. A., and Kuske, C. R.: Levels of Bacterial Community Diversity in Four Arid Soils Compared by Cultivation and 16S rRNA Gene Cloning, Appl. Environ. Microb., 65, 1662-1669, 1999.

Garbeva, P., Elsas, J. D., and Veen, J. A.: Rhizosphere microbial community and its response to plant species and soil history, Plant Soil, 302, 19-32, doi:10.1007/s11104-007-9432-0, 2008.

Gaby, J. C. and Buckley, D. H.: A global census of nitrogenase diversity, Environ. Microbiol., 13, 1790-1799, 10.1111/j.14622920.2011.02488.x, 2011.

Gaby, J. C. and Buckley, D. H.: A Comprehensive Evaluation of PCR Primers to Amplify the nifH Gene of Nitrogenase, PLoS ONE, 7, e42149, doi:10.1371/journal.pone.0042149, 2012.

Gros, R., Jocteur Monrozier, L., Bartoli, F., Chotte, J. L., and Faivre, P.: Relationships between soil physico-chemical properties and microbial activity along a restoration chronosequence of alpine grasslands following ski run construction, Appl. Soil Ecol., 27, 7-22, doi:10.1016/j.apsoil.2004.03.004, 2004.

Hamelin, J., Fromin, N., Tarnawski, S., Teyssier-Cuvelle, S., and Aragno, M.: nifH gene diversity in the bacterial community associated with the rhizosphere of Molinia coerulea, an oligonitrophilic perennial grass, Environ. Microbiol., 4, 477-481, doi:10.1046/j.1462-2920.2002.00319.x, 2002.

Hamilton, T., Boyd, E., and Peters, J.: Environmental Constraints Underpin the Distribution and Phylogenetic Diversity of nifH in the Yellowstone Geothermal Complex, Microb. Ecol., 61, 860870, doi:10.1007/s00248-011-9824-9, 2011.

Hayden, H. L., Drake, J., Imhof, M., Oxley, A. P. A., Norng, S., and Mele, P. M.: The abundance of nitrogen cycle genes amoA and nifH depends on land-uses and soil types in South-Eastern Australia, Soil Biol. Biochem., 42, 1774-1783, doi:10.1016/j.soilbio.2010.06.015, 2010.

Hsu, S. F. and Buckley, D. H.: Evidence for the functional significance of diazotroph community structure in soil, ISME J., 3, 124-136, doi:10.1038/ismej.2008.82, 2009.

Huang, L.-N., Tang, F.-Z., Song, Y.-S., Wan, C.-Y., Wang, S.-L., Liu, W.-Q., and Shu, W.-S.: Biodiversity, abundance, and activity of nitrogen-fixing bacteria during primary succession on a copper mine tailings, FEMS Microbiol. Ecol., 78, 439-450, doi:10.1111/j.1574-6941.2011.01178.x, 2011.

Huff, J. P., Grant, B. J., Penning, C. A., and Sullivan, K. F.: Optimization of routine transformation of Escherichia coli with plasmid DNA, BioTechniques, 9, 570-572, 1990.

Izquierdo, J. and Nüsslein, K.: Distribution of Extensive nifH Gene Diversity Across Physical Soil Microenvironments, Microb. Ecol., 51, 441-452, doi:10.1007/s00248-006-9044-x, 2006.

Jasrotia, P. and Ogram, A.: Diversity of nifH Genotypes in Floating Periphyton Mats Along a Nutrient Gradient in the Florida Everglades, Curr. Microbiol., 56, 563-568, doi:10.1007/s00284008-9124-x, 2008.

Jiang, C., Yu, G., Li, Y., Cao, G., Yang, Z., Sheng, W., and Yu, W.: Nutrient resorption of coexistence species in alpine meadow of the Qinghai-Tibetan Plateau explains plant adaptation to nutrient-poor environment, Ecol. Eng., 44, 1-9, doi:10.1016/j.ecoleng.2012.04.006, 2012.

Jukes, T. H. and Cantor, C. R.: Evolution of protein molecules, in: Mammalian protein metabolism, edited by: Munro, M. N., Academic Press, 21-132, 1969.
Jungblut, A. D. and Neilan, B. A.: NifH gene diversity and expression in a microbial mat community on the McMurdo Ice Shelf, Antarctica, Antarct. Sci., 22, 117-122, doi:10.1017/S0954102009990514, 2010.

Knelman, J. E., Legg, T. M., O’Neill, S. P., Washenberger, C. L., González, A., Cleveland, C. C., and Nemergut, D. R.: Bacterial community structure and function change in association with colonizer plants during early primary succession in a glacier forefield, Soil Biol. Biochem., 46, 172-180, doi:10.1016/j.soilbio.2011.12.001, 2012.

Kumar, S., Tamura, K., Jakobsen, I. B., and Nei, M.: MEGA2: molecular evolutionary genetics analysis software, Bioinformatics, 17, 1244-1245, doi:10.1093/bioinformatics/17.12.1244, 2001.

Li, X., Lu, L., Cheng, G., and Xiao, H.: Quantifying landscape structure of the Heihe River Basin, north-west China using FRAGSTATS, J. Arid Environ., 48, 521-535, doi:10.1006/jare.2000.0715, 2001.

Lifshitz, R., Kloepper, J. W., Scher, F. M., Tipping, E. M., and Laliberté, M.: Nitrogen-Fixing Pseudomonads Isolated from Roots of Plants Grown in the Canadian High Arctic, Appl. Environ. Microb., 51, 251-255, 1986.

Liu, G.-X., Hu, P., Zhang, W., Wu, X., Yang, X., Chen, T., Zhang, M., and Li, S.-W.: Variations in soil culturable bacteria communities and biochemical characteristics in the Dongkemadi glacier forefield along a chronosequence, Folia Microbiol., 57, 485-494, doi:10.1007/s12223-012-0159-9, 2012.

Lovell, C. R., Friez, M. J., Longshore, J. W., and Bagwell, C. E.: Recovery and Phylogenetic Analysis of nifH Sequences from Diazotrophic Bacteria Associated with Dead Aboveground Biomass of Spartina alterniflora, Appl. Environ. Microb., 67, 5308-5314, doi:10.1128/aem.67.11.5308-5314.2001, 2001.

Lozupone, C., Hamady, M., and Knight, R.: UniFrac - An online tool for comparing microbial community diversity in a phylogenetic context, BMC Bioinformatics, 7, 371-378, 2006.

Lynch, J. M. and Hobbie, J. E.: Micro-organisms in action: concepts and applications in microbial ecology, Blackwell Scientific Publications, 1988.

Ma, M. and Frank, V.: Interannual variability of vegetation cover in the Chinese Heihe River Basin and its relation to meteorological parameters, Int. J. Remote Sens., 27, 3473-3486, doi:10.1080/01431160600593031, 2006.

Moisander, P. H., Beinart, R. A., Voss, M., and Zehr, J. P.: Diversity and abundance of diazotrophic microorganisms in the South China Sea during intermonsoon, ISME J., 2, 954-967, http://www.nature.com/ismej/journal/v2/n9/suppinfo/ ismej200851s1.html, 2008.

Niederberger, T. D., Sohm, J. A., Tirindelli, J., Gunderson, T., Capone, D. G., Carpenter, E. J., and Cary, S. C.: Diverse and highly active diazotrophic assemblages inhabit ephemerally wetted soils of the Antarctic Dry Valleys, FEMS Microbiol. Ecol., 82, 376-390, doi:10.1111/j.1574-6941.2012.01390.x, 2012.

Nonnoi, F., Chinnaswamy, A., García de la Torre, V. S., Coba de la Peña, T., Lucas, M. M., and Pueyo, J. J.: Metal tolerance of rhizobial strains isolated from nodules of herbaceous legumes (Medicago spp. and Trifolium spp.) growing in mercury-contaminated soils, Appl. Soil Ecol., 61, 49-59, doi:10.1016/j.apsoil.2012.06.004, 2012. 
Olson, J. B., Steppe, T. F., Litaker, R. W., and Paerl, H. W.: $\mathrm{N}_{2}$-Fixing Microbial Consortia Associated with the Ice Cover of Lake Bonney, Antarctica, Microb. Ecol., 36, 231-238, doi:10.1007/s002489900110, 1998.

Palacios, R. and Newton, W. E.: Genomes and Genomics of Nitrogen-fixing Organisms, Nitrogen Fixation: Origins, Applications, and Research Progress; 3, Springer, Dordrecht, 2005.

Qian, P., Schoenaru, J. J., and Karamanos, R. E.: Simultaneous extraction of available phosphorus and potassium with a new soil test: A modification of Kelowna extraction, Commun. Soil Sci. Plan., 25, 627-635, doi:10.1080/00103629409369068, 1994.

Reed, S., Townsend, A., Cleveland, C., and Nemergut, D.: Microbial community shifts influence patterns in tropical forest nitrogen fixation, Oecologia, 164, 521-531, doi:10.1007/s00442-0101649-6, 2010.

Romero, I. C., Jacobson, M., Fuhrman, J. A., Fogel, M., and Capone, D. G.: Long-term nitrogen and phosphorus fertilization effects on $\mathrm{N}_{2}$ fixation rates and nifH gene community patterns in mangrove sediments, Mar. Ecol., 33, 117-127, doi:10.1111/j.1439-0485.2011.00465.x, 2012.

Rösch, C., Mergel, A., and Bothe, H.: Biodiversity of Denitrifying and Dinitrogen-Fixing Bacteria in an Acid Forest Soil, Appl. Environ. Microb., 68, 3818-3829, doi:10.1128/aem.68.8.38183829.2002, 2002.

Saitou, N. and Nei, M.: The neighbor-joining method: a new method for reconstructing phylogenetic trees, Mol. Biol. Evol., 4, 406425, 1987.

Shaffer, B. T., Widmer, F., Porteous, L. A., and Seidler, R. J.: Temporal and Spatial Distribution of the nifH Gene of $\mathrm{N}_{2}$ Fixing Bacteria in Forests and Clearcuts in Western Oregon, Microb. Ecol., 39, 12-21, doi:10.1007/s002489900183, 2000.

Steward, G. F., Zehr, J. P., Jellison, R., Montoya, J. P., and Hollibaugh, J. T.: Vertical Distribution of Nitrogen-Fixing Phylotypes in a Meromictic, Hypersaline Lake, Microb. Ecol., 47, 3040, doi:10.1007/s00248-003-1017-8, 2004.

Strassert, J. F. H., Köhler, T., Wienemann, T. H. G., Ikeda-Ohtsubo, W., Faivre, N., Franckenberg, S., Plarre, R., Radek, R., and Brune, A.: 'CandidatusAncillula trichonymphae', a novel lineage of endosymbiotic Actinobacteria in termite gut flagellates of the genus Trichonympha, Environ. Microbiol., 14, 3259-3270, doi:10.1111/1462-2920.12012, 2012.

Tamm, C. O.: Nitrogen in terrestrial ecosystems : questions of productivity, vegetational changes, and ecosystem stability, Ecological studies, 81, Springer, Berlin [etc.], 1991.

Teng, Q., Sun, B., Fu, X., Li, S., Cui, Z., and Cao, H.: Analysis of nifH gene diversity in red soil amended with manure in Jiangxi, south China, J. Microbiol., 47, 135-141, doi:10.1007/s12275008-0184-1, 2009.

Videira, S. S., De Araujo, J. L. S., Da Silva Rodrigues, L., Baldani, V. L. D., and Baldani, J. I.: Occurrence and diversity of nitrogen-fixing Sphingomonas bacteria associated with rice plants grown in Brazil, FEMS Microbiol. Lett., 293, 11-19, doi:10.1111/j.1574-6968.2008.01475.x, 2009.
Wang, N., Zhang, S., He, J., Pu, J., Wu, X., and Jiang, X.: Tracing the major source area of the mountainous runoff generation of the Heihe River in northwest China using stable isotope technique, Chinese Sci. Bull., 54, 2751-2757, doi:10.1007/s11434009-0505-8, 2009.

Xu, X., Ouyang, H., Kuzyakov, Y., Richter, A., and Wanek, W.: Significance of organic nitrogen acquisition for dominant plant species in an alpine meadow on the Tibet plateau, China, Plant Soil, 285, 221-231, doi:10.1007/s11104-006-9007-5, 2006.

Yuan, Z. Y., Li, L. H., Han, X. G., Huang, J. H., Jiang, G. M., Wan, S. Q., Zhang, W. H., and Chen, Q. S.: Nitrogen resorption from senescing leaves in 28 plant species in a semiarid region of northern China, J. Arid Environ., 63, 191-202, doi:10.1016/j.jaridenv.2005.01.023, 2005.

Zehr, J. P., Jenkins, B. D., Short, S. M., and Steward, G. F.: Nitrogenase gene diversity and microbial community structure: a cross-system comparison, Environ. Microbiol., 5, 539-554, doi:10.1046/j.1462-2920.2003.00451.x, 2003.

Zhan, J. and Sun, Q.: Diversity of free-living nitrogen-fixing microorganisms in wastelands of copper mine tailings during the process of natural ecological restoration, J. Environ. Sci., 23, 476-487, doi:10.1016/S1001-0742(10)60433-0, 2011.

Zhan, J. and Sun, Q.: Diversity of free-living nitrogen-fixing microorganisms in the rhizosphere and non-rhizosphere of pioneer plants growing on wastelands of copper mine tailings, Microbiol. Res., 167, 157-165, doi:10.1016/j.micres.2011.05.006, 2012.

Zhang, W., Zhang, G., Liu, G., Dong, Z., Chen, T., Zhang, M., Dyson, P. J., and An, L.: Bacterial diversity and distribution in the southeast edge of the Tengger Desert and their correlation with soil enzyme activities, J. Environ. Sci., 24, 2004-2011, doi:10.1016/S1001-0742(11)61037-1, 2012.

Zhang, Y., Li, D., Wang, H., Xiao, Q., and Liu, X.: Molecular diversity of nitrogen-fixing bacteria from the Tibetan Plateau, China, FEMS Microbiol. Lett., 260, 134-142, doi:10.1111/j.15746968.2006.00317.x, 2006.

Zhou, J., Xia, B., Treves, D. S., Wu, L.-Y., Marsh, T. L., O’Neill, R. V., Palumbo, A. V., and Tiedje, J. M.: Spatial and Resource Factors Influencing High Microbial Diversity in Soil, Appl. Environ. Microb., 68, 326-334, doi:10.1128/aem.68.1.326-334.2002, 2002.

Zou, Y., Zhang, J., Yang, D., Chen, X., Zhao, J., Xiu, W., Lai, X., and $\mathrm{Li}, \mathrm{G} .:$ Effects of different land use patterns on nifH genetic diversity of soil nitrogen-fixing microbial communities in Leymus Chinensis steppe, Acta Ecologica Sinica, 31, 150-156, doi:10.1016/j.chnaes.2011.03.004, 2011.

Zumsteg, A., Luster, J., Göransson, H., Smittenberg, R., Brunner, I., Bernasconi, S., Zeyer, J., and Frey, B.: Bacterial, Archaeal and Fungal Succession in the Forefield of a Receding Glacier, Microb. Ecol., 63, 552-564, doi:10.1007/s00248-011-9991-8, 2012. 